\title{
CONTROLLED WATER STRESS IN AGRICULTURAL CROPS IN BRAZILIAN CERRADO
}

\author{
ESTRESSE HÍDRICO CONTROLADO EM CULTURAS AGRÍCOLAS NO CERRADO \\ BRASILEIRO
}

\author{
Igor Silva SANTOS ${ }^{1}$; Everardo Chartuni MANTOVANI² ${ }^{2}$ Luan Peroni VENANCIO²; \\ Fernando França da CUNHA ${ }^{2}$; Catariny Cabral ALEMAN ${ }^{2}$ \\ 1. Irriger Gerenciamento de Irrigação, Uberaba, MG, Brazil. igor.santos@irriger.com.br; 2. Federal University of Viçosa, Agricultural \\ Engineering Department, Viçosa, MG, Brazil.
}

\begin{abstract}
Considering the scenarios with reduction of water availability, the need to increase water use efficiency and crop yield, the objective of this study was to evaluate the effect of reducing the evapotranspiration of the main irrigated crops on productivity. Data from the years 2005 to 2016 for carrot, garlic, potato, sugarcane, bean, maize, soybean, wheat, coffee and cotton crops grown in the Brazilian states of Bahia, Minas Gerais, São Paulo, Goiás, Distrito Federal and Mato Grosso were collected. The crops were irrigated by central-pivot irrigation and drip irrigation systems, and irrigation management was performed using IRRIGER $^{\circledR}$ software. With the information on potential crop evapotranspiration (ETpc) and crop evapotranspiration (ETc), it was possible to obtain a reduction of ETpc (\%) for all crops. For all scenarios, these data were confronted with crop productivity and regression models were fitted. It was concluded that the maximum reductions of ETpc (\%) without affecting productivity are 5\% for garlic and potato, $12 \%$ for maize, $13 \%$ for bean, $15 \%$ for wheat, $20 \%$ for soybean and cotton, $25 \%$ for sugarcane and $30 \%$ for coffee.
\end{abstract}

KEYWORDS: Irrigated agriculture. Evapotranspiration. Irrigation management.

\section{INTRODUCTION}

Irrigation is an essential factor for increasing the performance of agricultural crops, especially when used in the period of low occurrence of precipitation or irregular distribution (BRITO et al., 2017; FERREIRA et al., 2017). When irrigation is well managed, the plant expresses its production potential better and the use of water resources is optimized, guaranteeing greater sustainability (DAR et al., 2017; RODRIGUEZ-ORTEGA et al., 2017).

Several are the benefits that can be observed in the practice of irrigation, the main ones being: (i) increased productivity with water use efficiency two to three times higher than those obtained with rainfed agriculture; (ii) reduction of the unit cost of production; (iii) use of the agricultural area throughout the year with up to three harvests; (iv) intensive use of machines, implements and labor throughout the year; and (v) increase in the supply of food and other agricultural products on a regular basis throughout the year (OLIVEIRA et al., 2016; GRAFTON et al., 2018).

The search for high productivity and quality in production makes the adoption of irrigation practically indispensable in commercial crops in several Brazilian producing regions. When a given crop is irrigated, it is inevitable not to think about the concepts of how much and when to irrigate; however, irrigation or its broader concept of irrigated agriculture goes beyond these two concepts (EXPÓSITO; BERBEL, 2017). Thus, a theme that has been gaining prominence in recent years, motivated by the decrease in the availability of water resources and excessive increase in the cost of energy, is controlled water stress. This practice, among other advantages, allows less water consumption by agricultural crops without causing a significant reduction in productivity, resulting in a decrease in production costs.

Several research studies have been carried out in recent years involving the "water stress $\mathrm{x}$ productivity" relationship with very satisfactory results. Rao, Tanwar and Regar. (2016) point out that deficit irrigation may be an alternative under conditions of water availability constraints and may reduce production risks. Gava et al. (2016) working with the soybean crop found that deficit irrigation depths, when applied in the total cycle, reduced productivity. However, when applied only in subperiods, they did not differ from full irrigation. Locatelli et al. (2014), with different bean cultivars, observed that the application of irrigation depths based on 74.3 and $94.0 \%$ of the reference evapotranspiration led to maximum grain productivity of the cultivars BRS Guariba and BRS Novaera, respectively. 
Studies such as those mentioned above are of great importance, and their continuity is necessary considering the data from the Food and Agriculture Organization of the United Nations (FAO). According to the organization, Brazil uses $63 \%$ of its water resources for irrigation, $18 \%$ for human use, $14 \%$ for animal use and $5 \%$ for industrial use. The growth of the population, which by 2050 is expected to exceed two billion people, will require a $60 \%$ increase in food production, most of which is produced in irrigated areas. FAO predicts that irrigation in developing countries is expected to grow by as much as 20 percent by 2030 and that more efficient production systems with lower water consumption should be promoted by governments (GAVA et al., 2016; GAZZONI, 2017).

In view of the scenarios of reduction of water availability, the need to increase water use efficiency and maintenance of crop productivities, this study aimed to evaluate the effect of irrigation depths on the performance of the main Brazilian agricultural crops. With these results, the minimum values of evapotranspiration reduction were defined so as not to compromise the productivity of these agricultural crops.

\section{MATERIAL AND METHODS}

The research was conducted with harvest data collected from the years 2005 to 2016 for carrot, garlic, potato, sugarcane, bean, maize, soybean, wheat, coffee and cotton crops located in the states of Bahia (BA), Minas Gerais (MG), São Paulo (SP), Goiás (GO), Distrito Federal (DF) and Mato Grosso (MT). The agricultural crops mentioned above can be divided into three main groups: vegetables (garlic, carrots and potatoes), perennial crops (cotton, coffee and sugarcane) and grains (maize, soybeans, beans and wheat). The irrigation systems considered were drip and center pivot for coffee and only pivot for the other crops.

It is a wide range of scenarios that allow an extensive analysis of the effect of water stress. Such information was obtained by the company IRRIGER $^{\circledR}$, which is dedicated to the provision of consulting services related to irrigation management in extensive agricultural production area, using appropriate technical criteria and scientifically proven analytical tools.

Periodic visits were made to the regions of Triângulo Mineiro (Patrocínio-MG), Midwest (Cristalina-GO) and West of Bahia (Luís Eduardo Magalhães-BA), throughout 2016 and early 2017 to collect information about: local climatic data, crop evapotranspiration (ETc), potential crop evapotranspiration (ETpc), applied irrigations, rainfall, dates of planting and harvesting of monitored plots, and productivity.

Daily data were generated using IRRIGER ${ }^{\circledR}$ irrigation management software, where all necessary information such as crop, climatic, soil and equipment data were entered. With this software, the daily water balance was calculated, from the planting to the harvest of each plot. IRRIGER ${ }^{\circledR}$ software uses the using the modified FAO method (MFAO) for ETc determination (MANTOVANI; BERNARDO; PALARETTI, 2006; MANTOVANI; COSTA, 1998), according to Equation 1.

$\mathrm{ETc}=\mathrm{ETO}_{\mathrm{O}} \times \mathrm{K}_{r} \times \mathrm{K}_{\mathrm{T}_{\mathrm{L}}} \times \mathrm{K}_{\mathrm{S}}$

Where: ETc - crop evapotranspiration ( $\mathrm{mm}$ day $^{-1}$ ); ETo - reference evapotranspiration (mm day ${ }^{1}$ ); Kc - crop coefficient (dimensionless); Ks - soil moisture coefficient (dimensionless); $\mathrm{K}_{\mathrm{L}}$ - location coefficient (dimensionless).

The reference evapotranspiration (ETo) used by the GESAI method is that of PenmanMonteith (ALLEN et al., 1998). The values of crop coefficient $(\mathrm{Kc})$ vary with the type of crop, its stage of development, the length of its vegetative cycle and the local climatic conditions, and were obtained in Allen et al. (1998) and Bernardo et al. (2019). The soil moisture coefficient (Ks) was obtained by the Pierce model (BERNARDO; SOARES; MANTOVANI, 2006), according to Equation 2. The location coefficient $\left(\mathrm{K}_{\mathrm{L}}\right)$ was obtained by the Keller method (BERNARDO et al., 2019), according to Equation 3.

$\mathrm{K}_{\mathrm{S}}=\frac{\ln (\mathrm{CWD}+1]}{\ln [\mathrm{TWC}+1]}$

$\mathrm{K}_{\mathrm{I}_{\mathrm{e}}}=0.1 \sqrt{\mathrm{P}}$

Where: Ks - soil moisture coefficient (dimensionless); TWC - total soil water capacity (mm); CWD - current soil water depth (mm); $\mathrm{K}_{\mathrm{L}}$ irrigation location coefficient (dimensionless); P highest value among wet or shaded area percentage $(\%)$. CWD is calculated from difference between TWC and ETc accumulated in considered period (1 or more days), both in millimeters. When soil moisture is at field capacity, CWD is equal to TWC and, consequently, Ks is equal to 1 .

Soil samples were taken at depths of 0-20 $\mathrm{cm}, 20-40 \mathrm{~cm}$ and $40-60 \mathrm{~cm}$ for determinations of soil density by means of volumetric rings. The water contents equivalent to field capacity were obtained by the basin method (BERNARDO et al., 2019). The plant's permanent wilting points were obtained by means of the soil water retention curve, 
estimated for the $1,500 \mathrm{kPa}$ tension (BERNARDO et al., 2019).

The climatic data for the variables in the water balance equations were obtained from local meteorological stations, installed in the properties, which read the following parameters: relative air humidity, maximum, average and minimum temperatures, wind speed, solar radiation and precipitation. The meteorological stations are Davis brand Vantage Pro 2 model. Data are recorded every minute and transferred to the IRRIGER $^{\circledR}$ system, where the daily average of the site is generated.

In organizing all the information, 10,494 monitored plots were cataloged, varying among 44 irrigated crops, in 82 different cities distributed among the Brazilian states mentioned above. With the database organized, the analysis of the variables began. The organization of the final database involved careful analysis, eliminating those that were incomplete or inconsistent.

Initially the data were separated by crop with the objective of evaluating the range or point of reduction of ETpc (\%), at which the productivities were still high. ETpc reduction was calculated according to Equation 4. Productivity versus ETpc reduction $(\%)$ data were plotted, generating a cloud of points without specific behavior and with great variability.

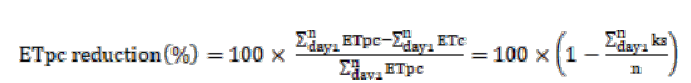

Where: ETpc - potential crop evapotranspiration (mm); ETc - crop evapotranspiration $(\mathrm{mm})$; Ks - coefficient of soil moisture (dimensionless).

The data variability was due to the differences between the controls and the plots, such as technical differences of management, genetic differences of the same crop, different fertilizations, sprays and phytosanitary problems and different production potentials between the genotypes. Based on the above, only a portion with higher productivity was considered for each value of ETpc reduction. Therefore, an attempt was made to reduce the random effect, listing only plots with the same productivity data for each ETpc value (\%). Thus, it was considered that crop management in all selected plots was adequate and there was minimal biotic or abiotic interference or random effect on it. In consequence, it was possible to separate the actual crop evapotranspiration daily, in each phase of its cycle, and the productivity maximum reached.

Table 1 presents the total number of plots and the selected number of plots for each crop. It is observed for some crops, like maize, that the reduction was very drastic. This was due to the fact that there are many plots with several productivities for the same value of ETpc reduction (\%).

Table 1. Number of plots evaluated considering the crops.

\begin{tabular}{lll}
\hline Crop & Total plots & Selected plots for analysis \\
\hline Garlic & 64 & 14 \\
Carrot & 132 & 14 \\
Potato & 769 & 18 \\
Bean & 1636 & 34 \\
Maize & 7598 & 60 \\
Wheat & 276 & 35 \\
Coffee & 392 & 57 \\
Sugarcane & 121 & 24 \\
Soybean & 1024 & 40 \\
Cotton & 533 & 39 \\
\hline
\end{tabular}

The data were submitted to regression analysis. The analysis was carried out using the "SigmaPlot 11.0" program (SYSTAT SOFTWARE, INC., 2011). The models were tested including the "Polynomial" and "Standard Curve" categories. Model selection was based on the regression coefficient significance, using the t-test with $10 \%$ probability level, on the determination coefficient $\left(\mathrm{R}^{2}\right)$ and on the biological phenomenon.

\section{RESULTS AND DISCUSSION}

Figure 1 shows the productivity behaviors of different crops according to the reduction of potential crop evapotranspiration (ETpc). It was verified in Figure 1A that there was no satisfactory fit for the carrot crop $\left(\mathrm{R}^{2}=0.03\right)$. Failure to fit the regression model to the data may be related to low sample sizes and also the high variability of the results. However, the dispersion of the data shows a reduction of productivity in relation to the reduction of ETpc. 

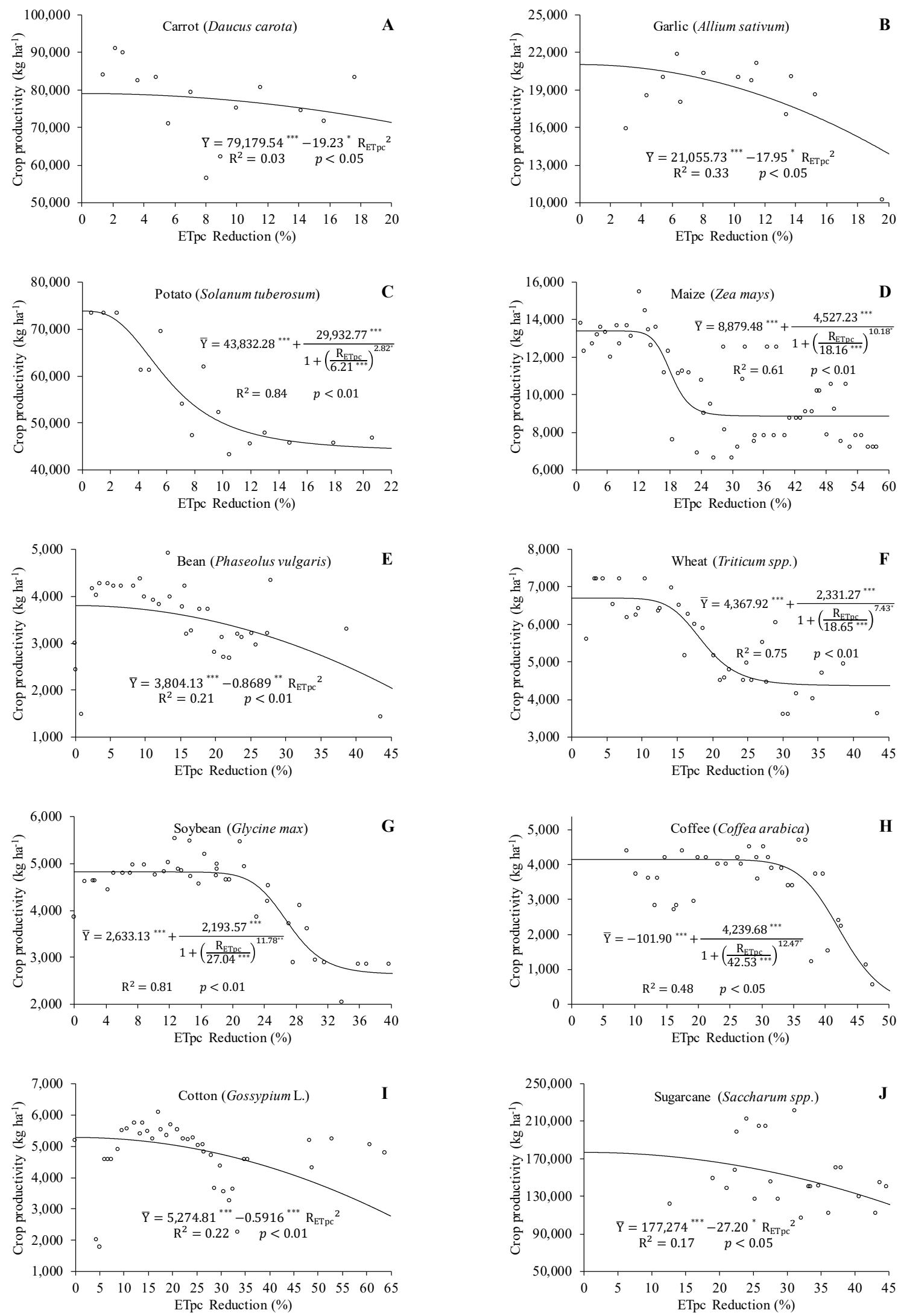

Figure 1. Productivity of agricultural crops: (A) carrot, (B) garlic, (C) potato, (D) maize, (E) bean, (F) wheat, (G) soybean, $(\mathrm{H})$ coffee, $(\mathrm{I})$ cotton and $(\mathrm{J})$ sugarcane as a function of the reduction of potential crop evapotranspiration (ETpc).

$* p<0.05 ; * * p<0.01 ; * * * p<0.001$ (Student's t-test). 
The carrot crop is highly sensitive to water deficit. The full development of the crop is obtained when the soil moisture is maintained close to field capacity during the whole cycle. The water requirement of the carrot crop varies from 350 to $800 \mathrm{~mm}$ (SANTOS et al., 2009; LÉLLIS et al., 2017; VAHRMEIJER et al., 2018), depending on the climatic conditions, cycle length, cultivar and irrigation. The daily demand of water increases slightly with the increase of leaf area, being maximum in the stage of tuberous root thickening. Lima Júnior et al. (2012) cultivated Nantes carrots and Nayarit F1 hybrid in soils with water contents equivalent to tensions between 15 and $75 \mathrm{kPa}$. For the two materials tested, the authors verified a reduction in productivity due to the reduction of soil water content, showing the importance of the water management of this crop. Carvalho et al. (2018) verified that the application of an irrigation depth corresponding to $100 \%$ replacement of crop evapotranspiration led to the highest productivity $\left(70 \mathrm{Mg} \mathrm{ha}^{-1}\right)$ of carrot roots, Brasília cultivar. In the treatments with smaller (43 and $72 \%$ of ETc) and larger $(120 \%$ of ETc) irrigation depths, the authors verified lower productivities. It should be pointed out that the application of higher irrigation depth does not cause higher evapotranspiration rates, since this excess irrigation fraction percolates to deeper soil horizons.

For the garlic crop, the best fit was the second-degree function, with low coefficient of determination (Figure 2B). However, when compared to the carrot, the tendency of decrease in productivity as a function of the reduction in ETpc is more noticeable, showing that garlic is sensitive to the small water deficit. The data of garlic water consumption in the present work differ from those found by Marouelli and Lucini (2014). The values described are between 400 and $850 \mathrm{~mm}$ and those found were between 297 and $555 \mathrm{~mm}$; this variation depends on the cycle of the studied variety, soil type and measurement criteria adopted. Spinelli et al. (2016) emphasize that, under conditions of water deficit, the physiological response is associated with stomatal closure, with negative impacts on evapotranspiration and consequent reduction of productivity.

The potato crop had the best fit among the crops studied ( $\mathrm{R}^{2}$ of 0.84 ). Figure $1 \mathrm{C}$ shows the great drop in productivity when there is a reduction of ETpc above 5\%. According to the regression equation, a $10 \%$ reduction in ETpc leads to a $32 \%$ drop in potato productivity. This shows that low soil water stress values possibly cause partial closure in the stomata of potato leaves and reduces $\mathrm{CO}_{2}$ assimilation (AZAD et al., 2018). Thus, irrigation management in the potato crop should be carried out in such a way that the current water table in the soil remains close to the limit representing its total water capacity to avoid large losses of productivity. On the other hand, it is worth pointing out that high soil moisture can lead to hypoxia (decreased $\mathrm{O}_{2}$ pressure) or anoxia (lack of $\mathrm{O}_{2}$ ), reducing plant metabolic activity, altering its metabolism and causing stress (MOREIRA et al., 2009).

For the vegetables, its verified that values of potential evapotranspiration reduction above 5\% lead to a considerable productivity reduction. Irrigated vegetables, being crops of very high added value and with a high cost of production (varying up to $\mathrm{R} \$ 100,000.00$ per hectare, as the irrigated garlic crop), do not tolerate water stress throughout the cycle. Thus, soil moisture can remain close to field capacity, except when it comes to preventive or corrective actions related to phytosanitary strategies and management strategies such as induction of bulb formation in garlic.

The maize crop showed an intermediate fit (Figure 1D). The reduction of up to $12 \%$ cannot be considered as impacting on productivity. Thus, in times of water scarcity, high costs with irrigation and low value of sale of the agricultural product, the irrigators will have the possibility of reducing irrigation by up to $12 \%$ and even so will get a positive balance at the end of the crop. However, studies show that the maize crop has different sensitivities to water deficit in the different stages of development. According to Ferreira et al. (2017), maize is relatively tolerant to water deficit during the vegetative stage, but is extremely sensitive in the flowering and grain filling stages, which can lead to decrease in productivity.

As the bean (Figure 1E) and wheat (Figure $1 \mathrm{~F})$ crops are cultivated in the period from February to August, very well defined curves were observed. Although the bean crop did not have a good fit $\left(\mathrm{R}^{2}=\right.$ $0.21)$, the fit was very good for wheat $\left(\mathrm{R}^{2}=0.75\right)$. By means of the regression equations, ETpc reductions of 13 and $15 \%$ for beans and wheat, respectively, lead to a reduction of $5 \%$ in grain productivity, and these reduction values are considered limits for a good irrigation management of these crops.

The decrease in bean productivity as a function of the reduction of ETpc (\%) can be explained by the fact that the water deficit reduces the water potential of the plants, decreasing conductance and leaf transpiration. The consequence of the situation is an increase in leaf temperature and a reduction in the production of 
photoassimilates, causing a reduction in crop productivity (GONZÁLEZ-REAL et al., 2017; AZAD et al., 2018). According to Carvalho et al. (2014) and Locatelli et al. (2014), the bean grain productivity is influenced by the water regime, which can affect root system growth, nutrient uptake and translocation.

Wheat has excellent genetic constitution and adaptability due to its high genotype $\mathrm{x}$ environment interaction; however, water stress is one of the factors that most limit the development and productivity of this crop in the Cerrado. Dar et al. (2017) verified this in their work, in which they found higher grain productivity and water productivity in treatments that received irrigation at all stages of wheat crop development. The authors also tested the CERES model (V4.6) and verified its efficiency in the productivity simulations for the crop, recommending that it should be considered in the decision making of wheat irrigation aiming at greater economic returns.

For the soybean crop a good fit $\left(\mathrm{R}^{2}=0.81\right)$ of the productivities was observed as a function of the reduction of ETpc. Being a tropical grain crop, soybean is one of the most tolerant to water stress. A very well defined curve is observed in Figure $1 \mathrm{G}$, and the value of $20 \%$ is the limit for working with water stress for this crop, without affecting its production. However, Gava et al. (2016) verified that productivity is affected by the occurrence of water deficit in the phenological period between pod formation and production formation. The occurrence of moderate and severe water deficits in the stages of vegetative development and flowering at the beginning of fruiting, affect the growth of the plants, but did not affect productivity. Giménez. Paredes and Pereira (2017) point out that soybean is sensitive to controlled water deficit from flowering to grain filling. However, the longer the exposure to the more severe water deficit, the greater the impacts on productivity.

In relation to the group of irrigated grains, it is known that they are crops of medium market value with great variation both in the cost of production (ranging from $\mathrm{R} \$ 1,500$ to $\mathrm{R} \$ 5,000.00$ per hectare) and in the price paid by the market at the time of sale. For maize, for example, in 2016 there were times when paid up R\$55.00 for the 60$\mathrm{kg}$ bag. At the same time in 2017, the same amount was worth R\$ 18.00. For beans, in 2016 there were times when we paid $\mathrm{R} \$ 500.00$ for the $60-\mathrm{kg}$ bag. In 2017, the same amount was worth R\$ 125.00. This, it's very risky for the producer conduct the crop under full irrigation, due to increase their cost its production. On the other hand, it also cannot save too much on irrigation and reduce its productivity. In coffee crop, the data fit to the model was median $\left(\mathrm{R}^{2}=0.48\right)$.

Arruda and Grande (2003), based on 16 years of coffee experiment, report that there is evidence that the increase in the age of the coffee crop increases its sensitivity to water stress. Possibly, this fact may have corroborated the increase in data variability in the present research. Nevertheless, the behavior of the curve (Figure 1H) shows that up to $30 \%$ reduction in ETpc can cause significant losses of coffee production. Possibly this high value occurs because the coffee crop needs water stress in the flowering stage (VICENTE et al., 2017). Thus, the plants will flourish at the same time, yielding grains with uniform maturity at the time of harvest and promoting good quality of the product. Vicente et al. (2015) concluded that the productivity of the coffee crop was dependent on the applied water depth recommended by IRRIPLUS ${ }^{\circledR}$ irrigation management software, and the highest productivity was obtained with $96 \%$ ETc depth. The water depth which led to the maximum percentage of fruits was 105\% ETc. The water depth which resulted in the highest water use efficiency was $75 \%$ ETc.

No good fit $\left(\mathrm{R}^{2}=0.22\right)$ was observed for the cotton crop due to the great variability of the data (Figure 1I). As a specific value, the parameter of $20 \%$ is suggested as the maximum limit for the practice of deficit irrigation, without losses in crop productivity. In order to reduce fruit productivity, it is necessary to reduce the productivity of fruit buds, flowers, and bolls, especially in the reproductive stage, resulting in lower vegetative growth, especially in height.

Figure 1J shows that the sugarcane and coffee crops also tolerate drought without major losses in production. And this is commonly seen in the production fields, where farmers are used to the practice of irrigation deficit, also known as "irrigation help". A very important aspect in the irrigation of sugarcane is the total soluble solids content ( ${ }^{\circ}$ Brix). There is a tendency of reduction in the degree Brix when the amount of irrigation is increased and the reduction of the ETpc (\%) is reduced. This is due to the higher dilution of soluble solids (sugars) in the broth due to the larger amount of water available in the soil and, consequently, in the stems, due to the higher irrigation depth applied, confirming Scarpari and Beauclair (2008). These authors observed that in areas where water availability is higher, ${ }^{\circ}$ Brix values are lower because of the dilution of sugars. 
For the perennial crops, ETpc reductions of up to $20 \%$ for coffee and cotton and $25 \%$ for sugarcane do not significantly compromise their productivities. These crops tolerate high values of water deficit throughout the cycle and, therefore, it is possible to irrigate with smaller depths without causing productivity losses.

The management techniques applied by the company IRRIGER ${ }^{\circledR}$ include water stress at the beginning of the development stage of the bean and garlic crops, which serve to induce root growth. This increases the reduction at this moment, since there is really the application of water stress in this stage. On the other hand, a few days before the flowering of bean and maize, for example, irrigations are more frequent and with depths that keep the soil moisture close to field capacity, which allows a better floral induction, favoring greater production of ears, pods and fruits per plant in the cultivated area. This technique, already consolidated in the field, also alters the ETpc reduction value (\%), decreasing it, because the soil moisture is always close to field capacity, exploiting the production potential of the crop.
It is worth mentioning that a more in-depth study of each crop is necessary, in relation to each stage of the cycle and its exact value of ETpc reduction (\%). Thus, at each stage of each crop, information on the use of water stress techniques without affecting the potential crop productivities will be known. This will lead to energy savings, less wear and tear of equipment, better manpower, better plant health, less occurrence of leaching of inputs and chemicals, and especially, the increasingly efficient use of water resources.

Table 2 presents the crops classified in groups as a function of the tolerable percentage of ETpc reduction without negative impacts on productivity. The carrot crop was isolated in a group without category, and the justification for this situation was the lack of fit in the regression model caused by the great variability of the crop data. The main highlight is the coffee and sugarcane crops, which had the highest tolerances, which justifies the use of deficit irrigation in some stages of these crops.

Table 2. Classification of crop groups according to the value of ETpc (\%) reduction

\begin{tabular}{ll}
\hline Group & Crop \\
\hline Without categories & Carrot \\
$1(0$ to $10 \%)$ & Garlic, Potato \\
$2(11$ to $15 \%)$ & Bean, Maize, Wheat \\
$3(16$ to $20 \%)$ & Cotton, Soybean \\
$4(>20 \%)$ & Coffee, Sugarcane \\
\hline
\end{tabular}

\section{CONCLUSIONS}

The maximum reductions of potential crop evapotranspiration without affecting productivity are $5 \%$ for garlic and potato crops, $12 \%$ for maize, $13 \%$ for bean, $15 \%$ for wheat, $20 \%$ for soybean and cotton, $25 \%$ for sugarcane and $30 \%$ for coffee.

\section{ACKNOWLEDGMENTS}

This study was financed in part by the Coordenação de Aperfeiçoamento de Pessoal de Nível Superior - Brasil (CAPES) - Finance Code 001

RESUMO: Diante dos cenários com redução da disponibilidade hídrica, necessidade de aumento da eficiência no uso da água e da produtividade das culturas agrícolas, objetivou-se neste trabalho avaliar o efeito da redução da evapotranspiração na produtividade das principais culturas irrigadas. Informações foram coletadas nas safras dos anos de 2005 à 2016 para as culturas da cenoura, alho, batata, cana-de-açúcar, feijão, milho, soja, trigo, café e algodão cultivadas nos estados da Bahia (BA), Minas Gerais (MG), São Paulo (SP), Goiás (GO), Distrito Federal (DF) e Mato Grosso (MT). As culturas foram irrigadas por sistemas de irrigação por pivô central e gotejamento, sendo que os manejos de irrigação foram realizados por meio do software IRRIGER $^{\circledR}$. Com as informações de evapotranspiração potencial da cultura (ETpc) e evapotranspiração da cultura (ETc) foi possível obter a redução da ETpc (\%) para todos os cultivos. Para todos os cenários, estes dados foram confrontados com a produtividade das culturas e modelos de regressão foram ajustados. Concluiuse que a redução máxima de ETpc (\%) sem afetar a produtividade é 5\% para o alho e batata, $12 \%$ para o milho, $13 \%$ para o feijão, $15 \%$ para o trigo, $20 \%$ para a soja e algodão, $25 \%$ para a cana-de-açúcar e $30 \%$ para o café. 
PALAVRAS-CHAVE: Agricultura irrigada. Evapotranspiração. Manejo da irrigação.

\section{REFERENCES}

ALLEN, R. G.; PEREIRA, L. S.; RAES, D.; SMITH, M. Crop evapotranspiration: guidelines for computing crop water requirements. Rome: FAO, 1998. 297p. (Irrigation and Drainage Paper, 56).

ARRUDA, F. B.; GRANDE, M. A. Fator de resposta da produção do cafeeiro ao deficit hídrico em Campinas. Bragantia, Campinas, v. 62, n. 1, p. 139-145, 2003. http://dx.doi.org/10.1590/S0006-87052003000100017

AZAD, N.; BEHMANESH, J.; REZAVERDINEJAD, V.; REZAIE, H. T. Climate change impacts modeling on winter wheat yield under full and deficit irrigation in Myandoab-Iran. Archives of Agronomy and Soil Science, v. 64, n. 5, p. 731-746, 2018. https://doi.org/10.1080/03650340.2017.1373187

BERNARDO, S.; MANTOVANI, E. C.; SOARES, A. A.; SILVA, D. D. Manual de Irrigação. 9. eds. Viçosa: Editora UFV, 2019. 545p.

BRITO, P. V. D. S.; MORAIS, Y. C. B.; FERREIRA, H. D. S.; SILVA, J. F.; GALVÍNCIO, J. D. Comparative analysis of moisture of vegetation of preserved caatinga areas, irrigated agriculture, and drought. Journal of Environmental Analysis and Progress, Recife, v. 2, n. 3, p. 493-498, 2017.

https://doi.org/10.24221/jeap.2.4.2017.1481.493-498

CARVALHO, D. F.; GOMES, D. P.; OLIVEIRA NETO, D. H.; ROUWS, J. R. C.; GUERRA, J. G. M.; OLIVEIRA, F. L. Carrot yield and water-use efficiency under different mulching, organic fertilization and irrigation levels. Revista Brasileira de Engenharia Agrícola e Ambiental, v. 22, n. 7, p. 445-450, 2018. https://doi.org/10.1590/1807-1929/agriambi.v22n7p445-450

CARVALHO, J. J.; SILVA, N. F.; ALVES, D. M.; MORAIS, W. A.; CUNHA, F. N.; TEIXEIRA, M. B. Produtividade e teores de nutrientes em grãos de feijão sob diferentes manejo do solo e da irrigação. Revista Brasileira de Agricultura Irrigada, Fortaleza, v. 8, n. 3, p. 296-307, 2014. https://doi.org/10.7127/RBAI.V8N300216

DAR, E. A.; BRAR, A. S.; MISHRA, S. K.; SINGH, K. B. Simulating response of wheat to timing and depth of irrigation water in drip irrigation system using CERES-Wheat model. Field Crops Research, New York, v. 214, n. 1, p. 149-163, 2017. https://doi.org/10.1016/j.fcr.2017.09.010

EXPÓSITO, A.; BERBEL, J. Why is water pricing ineffective for deficit irrigation schemes? A case study in southern Spain. Water Resources Management, Amsterdam, v. 31, n. 3, p. 1047-1059, 2017.

https://doi.org/10.1007/s11269-016-1563-8

FERREIRA, F. E. P.; PEREIRA, S. B.; MARTINEZ, M. A.; SOARES, A. R.; CUNHA, F. F. Uso do software Intecperímetro $^{\circledR}$ no manejo da irrigação da cultura do milho. Revista Científica Eletrônica de Agronomia, Garça, v. 32, n. 2, p. 1-7, 2017.

GAVA, R.; FRIZZONE, J. A.; SNYDER, R. L.; ALMEIDA, B. M.; FREITAS, P. S. L.; REZENDE, R. Estratégias de manejo de déficit hídrico na irrigação da cultura da soja. Revista Brasileira de Engenharia de Biossistemas, Tupã, v. 10, n. 3, p. 305-315, 2016. http://dx.doi.org/10.18011/bioeng2016v10n3p305-315

GAZZONI, D. L. Como alimentar 10 bilhões de cidadãos na década de 2050? Ciência e Cultura, São Paulo, v. 69, n. 4, p. 33-38, 2017. http://dx.doi.org/10.21800/2317-66602017000400012

GIMÉNEZ, L.; PAREDES, P.; PEREIRA, L. S. Water use and yield of soybean under various irrigation regimes and severe water stress. application of aquacrop and simdual kc models. Water, Switzerland, v. 9, n. 6, p. 393, 2017. https://doi.org/10.3390/w9060393 
GONZÁLEZ-REAL, M. M.; EGEA, G.; MARTIN-GORRIZ, B.; NORTES, P. A.; BAILLE, A. Spatial variability of soil $\mathrm{CO}_{2}$ efflux in drip-irrigated old and young citrus orchards and its dependence on biotic and abiotic factors. Geoderma, Amsterdam, v. 294, n. 1, p. 29-37, 2017.

https://doi.org/10.1016/j.geoderma.2017.01.036

GRAFTON, R. Q.; WILLIAMS, J.; PERRY, C. J.; MOLLE, F.; RINGLER, C.; STEDUTOR, P.; UDALL, B.; WHEELER, S. A.; WANG, Y. The paradox of irrigation efficiency: higher efficiency rarely reduces water consumption. Insights Policy Forum, Arlington, v. 361, n. 6404, p. 748-750, 2018.

https://doi.org/10.1126/science.aat9314

LÉLLIS, B. C.; CARALHO, D. F.; MARTÍNEZ-ROMERO, A.; TARJUELO, J. M.; DOMINGUEZ, A. Effective management of irrigation water for carrot under constant and optimized regulated deficit irrigation in Brazil. Agricultural Water Management, Amsterdam, v. 192, n. 1, p. 294-305, 2017.

https://doi.org/10.1016/j.agwat.2017.07.018

LIMA JUNIOR, J. A.; PEREIRA, G. M.; GEISENHOFF, L. O.; SILVA, W. G.; VILAS BOAS, R. C.; SOUZA, R. J. Desempenho de cultivares de cenoura em função da água no solo. Revista Brasileira de Engenharia Agrícola e Ambiental, Campina Grande, v. 16, n. 5, p. 514-520, 2012.

http://dx.doi.org/10.1590/S1415-43662012000500007

LOCATELLI, V. D. E.; MEDEIROS, R. D.; SMIDERLE, O. J.; ALBUQUERQUE, J. D. A.; ARAÚJO, W. F.; SOUZA, K. T. Componentes de produção, produtividade e eficiência da irrigação do feijão-caupi no cerrado de Roraima. Revista Brasileira de Engenharia Agrícola e Ambiental, Campina Grande, v. 18, n. 6, p. 574-580, 2014. http://dx.doi.org/10.1590/S1415-43662014000600002

MANTOVANI, E. C.; BERNARDO, S.; PALARETTI, L. F. Irrigação Principios e Métodos, 1. ed. Editora UFV: Viçosa, MG, 2006. 318p.

MANTOVANI, E. C.; COSTA, L. C. Manual Do SISDA 2.0, In: WORKSHOP INTERNACIONAL SOBRE MANEJO INTEGRADO DAS CULTURAS E RECURSOS HÍDRICOS. Anais... Viçosa, MG: UFV, 1998. $153 p$.

MAROUELLI, W. A.; LUCINI, M. A. Manejo de irrigação na cultura do alho. Pesquisa Agropecuária Catarinense, Florianópolis, v. 26, n. 3, p. 46-49, 2014.

MOREIRA, L. G.; VIANA, T. V. A.; MARINHO, A. B.; NOBRE, J. G. A.; LIMA, A. D.; ALBUQUERQUE, A. H. P. Efeitos de diferentes lâminas de irrigação na produtividade da mamoneira variedade IAC Guarani.

Revista Brasileira de Ciência Agrárias, Recife, v. 4, n. 4, p. 449-455, 2009.

http://dx.doi.org/10.5039/agraria.v4i4a13

OLIVEIRA, F. C.; GEISENHOFF, L. O.; ALMEIDA, A. C. S.; LIMA JÚNIOR, J. A.; LAVANHOLI, R. Economic feasibility of irrigation systems in broccoli crop. Engenharia Agrícola, Jaboticabal, v. 36, n. 3, p. 460-468, 2016. http://dx.doi.org/10.1590/1809-4430-Eng.Agric.v36n3p460-468/2016

RAO, S. S.; TANWAR, S. P. S.; REGAR, P. L. Effect of deficit irrigation, phosphorous inoculation and cycocel spray on root growth, seed cotton yield and water productivity of dripirrigated cotton in arid environment. Agricultural Water Management, Amsterdam, v. 169, n. 1, p. 14-25, 2016.

http://dx.doi.org/10.1016/j.agwat.2016.02.008

RODRIGUEZ-ORTEGA, W. M.; MARTINEZ, V.; RIVERO, R. M.; CAMARA-ZAPATA, J. M.; MESTRE, T.; GARCIA-SANCHEZ, F. Use of a smart irrigation system to study the effects of irrigation management on the agronomic and physiological responses of tomato plants grown under different temperatures regimes.

Agricultural Water Management, Amsterdam, v. 183, n. 1, p. 158-168. 2017.

http://dx.doi.org/10.1016/j.agwat.2016.07.014 
SANTOS, F. X.; MONTENEGRO, A. A. A.; SILVA, J. R.; SOUZA, E. R. Determinação do consumo hídrico da cenoura utilizando lisímetros de drenagem, no agreste pernambucano. Revista Brasileira de Ciências Agrárias, Recife, v. 4, n. 3, p. 304-310, 2009. http://dx.doi.org/10.5039/agraria.v4i3a13

SCARPARI, M. S.; BEAUCLAIR, E. G. F. Variação espaço-temporal do índice de área foliar e brix em canade-açúcar. Bragantia, Campinas, v. 67, n. 1, p. 35-41, 2008. http://dx.doi.org/10.1590/S000687052008000100004

SPINELLI, G. M.; SNYDER, R. L.; SANDENC, B. L.; SHACKEL, K. A. Water stress causes stomatal closure but does not reduce canopy evapotranspiration in almond. Agricultural Water Management, Amsterdam, v. 168, n. 1, p. 11-22, 2016. http://dx.doi.org/10.1016/j.agwat.2016.01.005

SYSTAT SOFTWARE, INC. SigmaPlot for Windows, version 11.0. 2011.

VAHRMEIJER, J. T.; ANNANDALE, J. G.; STEYN, J. M.; BRISTOW, K. L. Model parameters of four important vegetable crops for improved water use and yield estimation. Water, Gezina, v. 44, n. 4, p. 528-538, 2018. http://dx.doi.org/10.4314/wsa.v44i4.02

VICENTE, M. R.; MANTOVANI, E. C.; FERNANDES, A. L. T.; DELAZARI, F. T.; FIGUEIREDO, E. M. Efeito de diferentes lâminas de irrigação nas variáveis de desenvolvimento e produção do cafeeiro irrigado por pivô central. Irriga, Botucatu, v. 20, n. 3, p. 528-543, 2015. http://dx.doi.org/10.15809/irriga.2015v20n3p528

VICENTE, M. R.; MANTOVANI, E. C.; FERNANDES, A. L. T.; NEVES, J. C. L.; DELAZARI, F. T.; FIGUEIREDO, E. M. Efeitos da irrigação na produção e no desenvolvimento do cafeeiro na região oeste da Bahia. Coffee Science, Lavras, v. 12, n. 4, p. 544-551, 2017. http://dx.doi.org/10.25186/cs.v12i4.1367 